\title{
INTRODUCTION TO ARGUMENT-ENCODING SYSTEMS IN BOLIVIAN AMAZONIAN LANGUAGES ${ }^{1}$
}

\author{
Antoine Guillaume and Françoise Rose \\ Laboratoire DynamiQue Du Langage, CNRS, AND Université Lyon 2
}

\begin{abstract}
Here we offer a brief introduction to this special issue on argument-encoding systems of the little-known languages of Bolivian Amazonia, a region extremely rich linguistically. After providing some information on the sociolinguistic settings and the history of linguistic research in this area, we focus on the domain of argument-encoding systems in those languages and show how very diverse types of systems are found in languages spoken in very close proximity, including hierarchical/inverse cross-referencing systems, ergative systems, and split-intransitive systems. We also point to a number of typologically and theoretically interesting phenomena found in these languages, such as fluid transitivity, double-object ditransitive constructions, and rare valency-changing derivations such as multiple applicatives and sociative causatives.

[KeYwords: Bolivia, Amazonian languages, argument structure, cross-referencing, case]
\end{abstract}

1. Introduction. The collection of articles in this volume originated in a workshop that we organized on argument-encoding systems in Bolivian lowland languages at the Centre d'Etudes des Langues Indigènes d'Amérique (CNRS/IRD, Villejuif, France) in May 2007. ${ }^{2}$ The first incentive for the workshop, and subsequently the collection of articles included here, was the strengthening of an emerging network of a new generation of field linguists writing descriptions of indigenous Amazonian languages of Bolivia. The second was to promote research and interactions on argument structure in Amazonian Bolivia, the diversity and complexity of this domain in Amazonian languages being to date underrepresented in general typological

\footnotetext{
${ }^{1}$ We thank all the authors who contributed papers to this collection for their comments on earlier versions of this introduction; thanks also to an anonymous IJAL associate editor.

${ }^{2}$ We thank the Institut National des Langues et Civilisations Orientales (INALCO) and the Centre d'Etudes des Langues Indigènes d'Amérique (CELIA, CNRS/IRD) for financing the workshop. Also, we would like to acknowledge the participation in this workshop of the following linguists (whose papers do not appear in this collection): Östen Dahl (paper on Siriono), Carola Emkow (paper on Araona), Oliver Iggesen (paper on Chácobo), and Marine Vuillermet (paper on Ese Ejja); the titles of their 2007 presentations appear in the list of references at the end of this introduction. Finally, we are grateful to the following people for reviewing the papers in this volume: Denis Creissels, Scott DeLancey, Alexandre François, Spike Gildea, Doris Payne, Pilar Valenzuela, Fernando Zúñiga, and an anonymous IJAL associate editor.
}

[IJAL vol. 77, no. 4, October 2011, pp. 459-68]

(C) 2011 by The University of Chicago. All rights reserved.

$0020-7071 / 2011 / 7704-0001 \$ 10.00$ 
TABLE 1

Indigenous LANGUAGES of AMAZONIAN Bolivia

\begin{tabular}{|c|c|c|c|}
\hline Family & Language & Number of Speakers & $\begin{array}{c}\text { Number of Ethnic } \\
\text { Group Members }\end{array}$ \\
\hline \multirow[t]{5}{*}{ Arawak } & Baure & 67 & 886 \\
\hline & Machineri & 13 & 30 \\
\hline & Mojeño Ignaciano / & & \\
\hline & Mojeño Trinitario & $1,080 / 3,140$ & $2,000 / 30,000$ \\
\hline & Paunaca & 5 & $?$ \\
\hline Chapacuran & Moré & 44 & 64 \\
\hline \multirow[t]{3}{*}{ Pano } & Chácobo & 380 & 516 \\
\hline & Pacahuara & 6 & 46 \\
\hline & Yaminawa & 51 & 93 \\
\hline \multirow[t]{5}{*}{ Tacanan } & Araona & 111 & 158 \\
\hline & Cavineña & 601 & 1,683 \\
\hline & Ese Ejja & 518 & 732 \\
\hline & Reyesano (Maropa) & 12 & 4,919 \\
\hline & Tacana & 50 & 7,345 \\
\hline \multirow[t]{3}{*}{ Tupi } & Guarayo & 8,433 & 11,953 \\
\hline & Siriono & 187 & 268 \\
\hline & Yuki & 140 & 208 \\
\hline \multirow[t]{8}{*}{ Unclassified } & Canichana & 0 & 404 \\
\hline & Cayubaba & $<5$ & 664 \\
\hline & Chiquitano & 4,615 & 195,624 \\
\hline & Itonama & $<2$ & 2,791 \\
\hline & Leko & 20 & 4,186 \\
\hline & Mosetén/Chimane & $948 / 6,351$ & $1,588 / 8,615$ \\
\hline & Movima & 1,173 & 12,230 \\
\hline & Yurakaré & 1,809 & 2,829 \\
\hline
\end{tabular}

This table is based on Crevels and Muysken (2009). Note that we are only including languages which are spoken (at least partly) in the Amazonian river basin. The Bolivian Lowlands also include languages from the Chaco region, further to the south (i.e., in the Rio de la Plata basin), some of which are direct neighbors of the Amazonian languages: Ayoreo (Zamucoan), Chiriguano and Tapiete (Tupi), and Mataco (Matacoan).

and theoretical work (e.g., Derbyshire 1987, Payne 1990:4, and Dixon 1994:xv). For this collection, we add a third incentive: to raise awareness in the academic world of these little-known languages.

2. The indigenous languages of Amazonian Bolivia. The Amazonian lowlands of Bolivia are linguistically a particularly rich and diverse area, with about 20-25 different indigenous languages, listed in table 1. Eight are unclassified/isolates and the others belong to five different families. (See also figure 1.) 


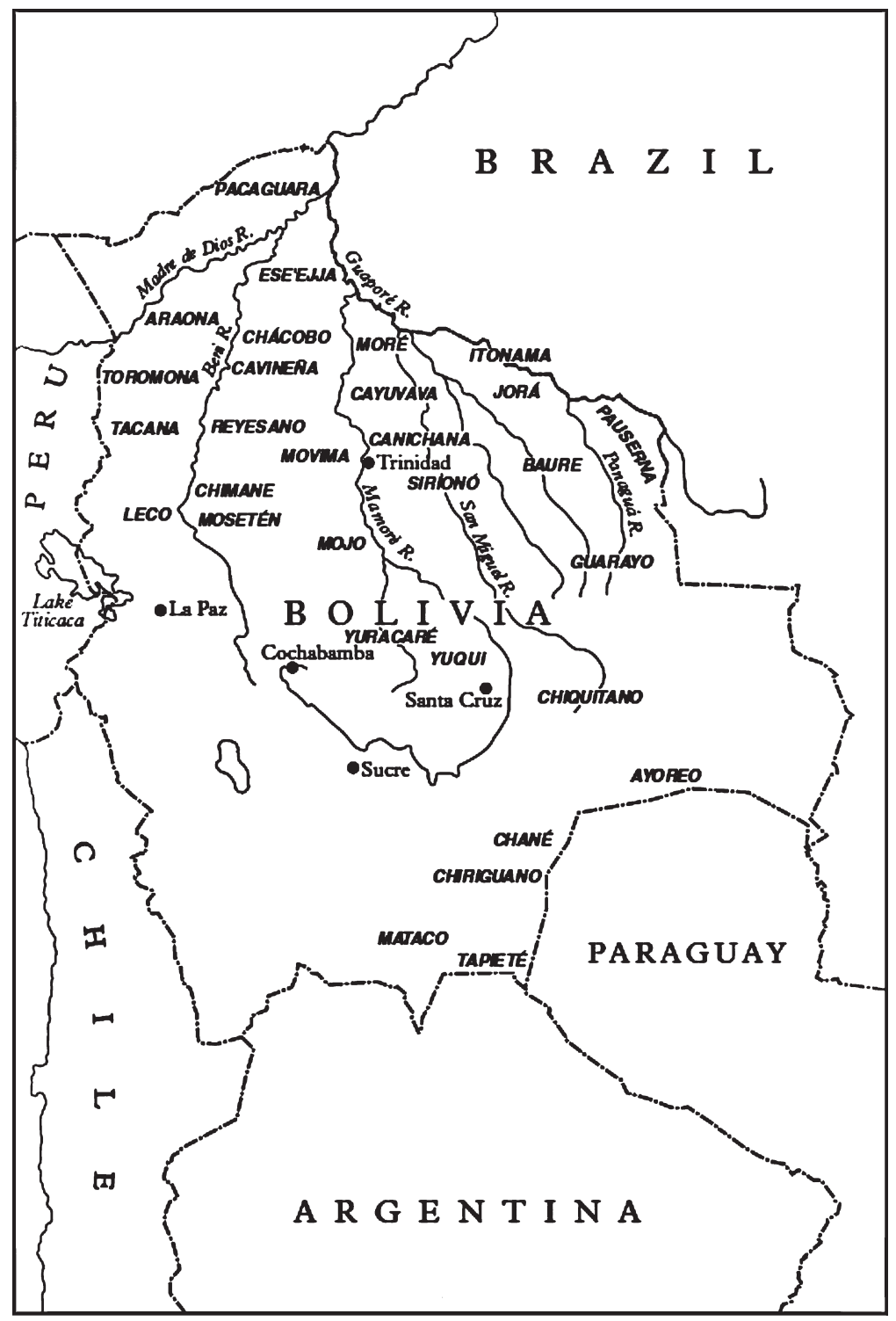

FIG. 1.-The languages of Lowland Bolivia (from Adelaar 2004:414). [This map was originally published in The Languages of the Andes, by Willem F. H. Adelaar, with Pieter C. Muysken. Copyright (C) 2004 Willem F. H. Adelaar and Pieter C. Muysken. Reprinted with the permission of Cambridge University Press.] 
This diversity is seriously threatened as these languages are spoken by a limited number of speakers (a few thousand at best, as shown in table 1) and are in most cases not being passed on to the younger generations (see Crevels 2002 for a historical and sociolinguistic overview of these languages and their endangerment status).

Lowland Bolivia is situated at the margins of the Amazon basin, in its southwestern part, next to the Andean region to the west and the Rio de la Plata basin to the south. This region is characterized by extraordinarily high ethnic, linguistic, and cultural diversity. The combination of the features of high diversity and endangerment led Anderson and Harrison (2007) to consider the Bolivian lowlands to be one of five major hotspots of linguistic diversity in the world. ${ }^{3}$

The origin of the present indigenous populations of the area is complex, due to forced relocation and regrouping of people during the Mission period (in the seventeenth and eighteenth centuries) and the Rubber Period (from the late nineteenth to early twentieth century) (see Crevels 2002). In particular, the language policy of the missions tended to blur the original ethnic and linguistic distinctions, by the "reduction" of several communities within the same mission and by substituting a "general language" based on a locally dominant indigenous language for the diversity of the local native languages (Saito 2009).

3. Linguistic studies. Until recently, little was known about the languages of Amazonian Bolivia, apart from short word lists collected by travelers or sketchy grammatical descriptions and dictionaries by the Summer Institute of Linguistics. However, the research on these languages has developed considerably during the past $10-15$ years, thanks to a new generation of European ${ }^{4}$ academic linguists dedicated to fieldwork and working from a general functional/typological perspective. Today, about 15 of the 20-odd languages of the region are being investigated. Two important projects formed the starting point of the current description of Bolivian Amazonian languages: a government-sponsored campaign for the standardization of the alphabets of lowland languages in 1995-96, funded by UNESCO and coordinated by C. Grinevald (Université Lyon 2), and

\footnotetext{
${ }^{3}$ The other hotspot of linguistic diversity in South America identified by these authors is the Amazonian Lowland area northeast of Peru, east of Ecuador, and southeast of Colombia.

${ }^{4}$ Note that until very recently, the Bolivian academic environment did not train linguists to describe the indigenous languages of the Lowlands. Most Bolivian linguists work on languages of the highlands or on local Spanish. Moreover, there is no tradition of Bolivian students going abroad to be trained in linguistics (unlike what happens in many other South American countries). Things are changing though, with some recent initiatives like the "Curso de formación en lingüística para maestros indígenas de tierras bajas de Bolivia," organized since 2006 by the Universidad Autónoma "Gabriel René Moreno" (UAGRM, Santa Cruz).
} 
the "Lexicon and Syntax" project (1999-2004), funded by a Spinoza grant from the Netherlands Organization for Scientific Research (NWO), headed by P. Muysken (then at the University of Leiden, now at Radboud University) and coordinated in Bolivia by M. Crevels. These two projects, together with funding from the Research Centre of Linguistic Typology of La Trobe University, allowed a number of European graduate students and postdoctoral researchers to undertake fieldwork in the region, and resulted in the production of the first detailed reference grammars of several languages of the area, including Sakel (2004) on Mosetén, Villafañe (2004) on Yuki, Emkow (2006) on Araona, Haude (2006) on Movima, van Gijn (2006) on Yurakaré, Danielsen (2007) on Baure, and Guillaume (2008a) on Cavineña.

An increased knowledge of languages of Amazonian Bolivia opens up new directions for research, including work in diachronic and areal studies which could help revise contested language classifications that were established when those languages were little known, such as Greenberg's (1987) macro-classification (note the critiques of this classification by Kaufman 1990, Campbell 1997, and Dixon and Aikhenvald 1999). ${ }^{5}$ Areal studies could also help clarify the typological and historical relation of the local languages with other Amazonian languages or with languages of the Andeas or the Rio de la Plata basin.

4. Argument-encoding systems in Amazonian Bolivia languages. One particular domain of interest in languages of this area is argument structure, the focus of this collection. There is a striking variety of systems found in languages spoken in close proximity. First, if we look at the morphosyntactic means of argument encoding, apart from constituent order, the following devices are found: ${ }^{6}$

- Verbal cross-referencing (via affixes or clitics): Baure and Mojeño (Arawak), Itonama (Isolate), Leko (Isolate) (van de Kerke 2006), Mosetén-Chimane (Isolate), Reyesano (Tacanan), Siriono (TupiGuarani) (Hemmauer 2006 and Dahl 2007), and Yurakaré (Isolate)

- Second-position clitics: Cavineña (Tacanan)

- Case marking: Araona, Cavineña, Ese Ejja, and Tacana (Tacanan), Chácobo $^{7}$ (Panoan) (Valenzuela [n.d.] and Iggesen 2007), Yaminawa (Panoan) (Valenzuela 2000 and Faust and Loos 2002), and Leko (Isolate) (van de Kerke 2006)

\footnotetext{
5 See, for example, Crevels and van der Voort's (2008) areal study on the languages of lowland Bolivia and the neighboring Brazilian state of Rondonia.

${ }^{6}$ In the following list, when no reference is provided, the language is discussed in a paper in this volume.

${ }^{7}$ Chácobo is also noteworthy for marking the ergative case suprasegmentally, by moving the stress to the last syllable (Valenzuela [n.d.] and Iggesen 2007).
} 
Second, if we consider the domain of alignment, all major types of patterns are represented in these languages:

- Nominative-accusative: Leko (Isolate) (van de Kerke 2006) and Yurakaré (Isolate)

- Ergative-absolutive: Araona, Cavineña, Ese Ejja, and Tacana (Tacanan), Chácobo (Panoan) (Valenzuela [n.d.] and Iggesen 2007), and Yaminawa (Panoan) (Valenzuela 2000 and Faust and Loos 2002)

- Split intransitive (active/inactive): Baure and Mojeño (Arawak), Siriono (Tupi-Guarani) (Hemmauer 2006 and Dahl 2007), and Yuki (TupiGuarani) (Villafañe 2004)

Finally, the argument-encoding systems of these languages display a number of phenomena rarely attested elsewhere:

- Hierarchical and inverse cross-referencing systems in transitive clauses, whereby the $\mathrm{A}$ and $\mathrm{O}$ arguments are marked according to their ranking on a referential/nominal hierarchy, rather than according to their grammatical function (see Zúñiga 2006). Such systems are reported in the three isolates Movima (Haude 2006:257ff.; 2009; and her paper in this volume), Mosetén-Chimane (see Sakel's paper in this volume), and Itonama (see Crevels's paper in this volume), in the Tupi-Guarani languages Siriono (Hemmauer 2006 and Dahl 2007) and Yuki (Villafañe 2004:105-8), and in the Tacanan language Reyesano (Guillaume 2009 and his paper in this volume)

- Multiple-split ergative systems, as in the Panoan language Chácobo (Valenzuela [n.d.] and Iggesen 2007) ${ }^{8}$

- Split intransitive systems conditioned by the word class of the predicate head, whether a verb or a noun (rather than by the aspect of the predicate or the agentivity of the unique argument). Such systems are found in the two Arawak languages Baure (Danielsen and Granadillo 2008) and Mojeño Trinitario (see Rose's paper in this volume)

- Fluid transitivity with differential S/A marking conditioned by syntactic, semantic, and discourse factors, as in the Arawak language Mojeño Trinitario (see Rose's paper in this volume)

- Double-object ditransitive constructions, where theme and recipient arguments are treated identically by overt encoding devices and behavior-and-control properties. This is found in the Tacanan language Cavineña (Guillaume 2008b)

- Multiple applicative derivations, with five different applicative markers in Mosetén (Sakel 2004:318-25), five in Yurakaré (van Gijn 2006:148-69 and his paper in this volume), six in Movima (Haude 2006:397-420),

\footnotetext{
${ }^{8}$ An analysis in terms of a multiple-split ergative system has also been proposed for the Tacanan language Cavineña (Camp 1985 and Dixon 1994:106-7). However, this analysis has been refuted by Guillaume (2006a; 2010).
} 
and two to three in the two Arawak languages Baure (Danielsen 2007:242-44, 252-53) and Mojeño Trinitario (Rose [forthcoming])

- Specialized sociative causative markers, which express the fact that the causer not only makes the causee do an action but also participates in it (Guillaume and Rose 2010). Such types of markers are found in (at least) the isolate language Mosetén-Chimane (Sakel 2004), the Tupi-Guarani language Yuki (Villafañe 2004), and the four Tacanan languages Cavineña (Guillaume 2008a), Ese Ejja (see Vuillermet [forthcoming]), Reyesano (see Guillaume 2006b; forthcoming), and Tacana (Guillaume fieldnotes)

5. Contents. The papers in this collection show the diversity and theoretical challenges raised by the argument-encoding systems in Bolivian Amazonian languages. They present studies and data from languages of two families-Arawak (Mojeño Trinitario and Baure) and Tacanan (Araona, Cavineña, Ese Ejja, Reyesano, and Tacana) and four isolates (Itonama, Mosetén-Chimane, Movima, and Yurakaré).

Rose describes the person indexation system of Mojeño Trinitario and discusses its S/A differential marking. Third-person subject can be indexed by an unspecified third-person prefix or by a third-person prefix that specifies animacy, number, gender of the referent, and gender of the speaker for reference-tracking purposes. The distribution of these types of third-person subject encoding is based on a transitivity continuum depending on grammatical, semantic, and discourse factors.

Danielsen compares the Baure person paradigm with those of other South Arawak languages (Paunaca, Mojeño, Terêna, the Apuriña/Piro/Iñapari subgroup, the Campa languages Ashéninka and Asháninka, and the Southwestern Arawak languages Amuesha and Chamicuro) and proposes a reconstruction of person marking for South Arawak.

The paper by Guillaume takes a comparative-historical look at a verbal suffix - ta that appears in the five languages of the Tacanan family. In four of these languages, this suffix marks a third-person plural $\mathrm{S}$ argument within an intransitive clause and a third-person A argument within a transitive clause. In the fifth, it is a passive marker. Guillaume argues that these suffixes are cognate and that their origin can be traced back to a third-person plural marker.

The paper by Sakel on Mosetén-Chimane is an investigation of the intricate system of cross-reference of person, number, and gender of the core arguments on the verbs. In earlier work, Sakel (2004:185-91) treated most of the forms as fused (portmanteau) morphemes. Here, she shows that a person hierarchy and different configurations of participants can explain most forms. The remaining portmanteau morphemes are restricted to local configurations $(1 \leftrightarrow 2$ ), which is a cross-linguistically widespread phenomenon (see Heath 1998). She also shows that in mixed configurations (SAP $\leftrightarrow 3$ ), the third person is marked, outranking SAPs. Moreover, in $3 \leftrightarrow 3$ configurations, the 
patient form is used, outranking the agent. In other words, person and semantic role hierarchies seem to operate in reverse order than what is commonly expected on typological grounds.

Haude's paper on Movima focuses on the encoding of SAPs within a hierarchical and inverse system. Expanding on previous work (Haude 2009), the author shows that except for second-person plural marking, local configurations essentially conform to the same hierarchical and inverse marking that characterize the other configurations. This property makes the Movima inverse system typologically unusual, as it is rare to find languages with inverse marking in all three configurations (local, mixed, and non-local). Finally, Haude shows a striking phenomenon where under certain discoursepragmatic circumstances the discourse status of a referent can override the person hierarchy.

The paper by Crevels on Itonama describes another type of inverse system. The system in this language shows overt marking for the inverse configuration but not for the direct one. Inverse marking only applies in independent clauses and only in mixed configurations $(3 \leftrightarrow \mathrm{SAP})$. An interesting feature is that in independent clauses, inverse marking combines with a nominative-accusative alignment. By contrast, in dependent clauses, inverse marking is not found and the nominative-accusative pattern is the unique principle at work.

Van Gijn describes subject and object encoding on verbs in Yurakaré, taking a semantic perspective. There is a rich system of six objects in Yurakaré, all head-marked on the verb. Five of them could be considered as applied objects, but van Gijn argues that they are equivalent types of objects, each with a distinct functional-semantic and morphosyntactic coherence. The six object types form a symmetrical system, with three groups (patients, goals, and comitatives), each with two variants (a directly involved participant and an indirectly involved participant). The choice of argument encoding is determined by verb semantics organized along scales of transitivity factors like affectedness of $\mathrm{O}$ and agentivity of $\mathrm{A}$.

\section{REFERENCES}

AdelaAr, Willem F. H. 2004. The Languages of the Andes. In collaboration with Pieter C. Muysken. Cambridge: Cambridge University Press.

Anderson, Gregory, AND David K. HARrison. 2007. Global Language Hotspots. < http://www. swarthmore.edu/SocSci/langhotspots/index.html>.

CAMP, Elizabeth L. 1985. Split ergativity in Cavineña. IJAL 51:38-58.

CAmpbell, Lyle. 1997. American Indian Languages: The Historical Linguistics of Native America. Oxford: Oxford University Press.

CREvels, Mily. 2002. Why speakers shift and languages die: An account of language death in Amazonian Bolivia. Current Studies on South American Languages, ed. Mily Crevels et al., pp. 9-30. Leiden: CNWS.

Crevels, Mily, and Pieter Muysken. 2009. Lenguas de Bolivia: Presentación y antecedentes. Lenguas de Bolivia, vol. 1, Ambito andino, ed. Mily Crevels and Pieter Muysken, pp. 13-26. LaPaz: Plural Editores. 
Crevels, Mily, and Hein van der Voort. 2008. The Guaporé-Mamoré region as a linguistic area. From Linguistic Areas to Areal Linguistics, ed. Pieter Muysken, pp. 151-79. Amsterdam and Philadelphia: John Benjamins.

Dahl, Östen. 2007. Argument coding in Sirionó. Paper presented at the Workshop on Argument-Coding Systems in Bolivian Lowland Languages, CELIA, Villejuif, April 5-7, 2007.

DANIELSEn, Swintha. 2007. Baure, an Arawak Language of Bolivia. Leiden: CNWS.

Danielsen, Swintha, and Tania Granadillo. 2008. Agreement in two Arawak languages: Baure and Kurripako. The Typology of Semantic Alignment, ed. Mark Donohue and Søren Wichmann, pp. 396-411. Oxford: Oxford University Press.

DERbyshire, DESMOND. 1987. Morphosyntactic areal characteristics of Amazonian languages. IJAL 53:311-26.

DiXON, R. M. W. 1994. Ergativity. Cambridge: Cambridge University Press.

Dixon, R. M. W., And A. Y. Aikhenvald. 1999. Introduction. The Amazonian Languages, ed. R. M. W. Dixon and A. Y. Aikhenvald, pp. 1-21. Cambridge: Cambridge University Press.

EMKow, CARolA. 2006. A grammar of Araona, an Amazonian language of northern Bolivia. Ph.D. dissertation, La Trobe University.

2007. Grammatical relations in Araona. Paper presented at the Workshop on ArgumentCoding Systems in Bolivian Lowland Languages, CELIA, Villejuif, April 5-7, 2007.

FAust, Norma, And Eugene E. Loos. 2002. Gramática del idioma yaminahua. Lima: Instituto Lingüístico de Verano.

Greenberg, Joseph. 1987. Language in the Americas. Palo Alto, Calif.: Stanford University Press.

Guillaume, Antoine. 2006a. Revisiting "split ergativity" in Cavineña. IJAL 72:159-92.

2006b. A Reyesano (Maropa)-English dictionary, with grammatical notes. Ms. (169 pages).

2008a. A Grammar of Cavineña. Berlin and New York: Mouton de Gruyter.

2008b. Ditransitivité en cavineña: Constructions à objet double. Amerindia 31:135-56.

2009. Hierarchical agreement and split intransitivity in Reyesano. IJAL 75:29-48.

2010. How ergative is Cavineña? Ergativity in Amazonia, ed. S. Gildea and F. Queixalós, pp. 97-120. Amsterdam and Philadelphia: John Benjamins.

. Forthcoming. Maropa (reyesano). Lenguas de Bolivia, vol. 2, Amazonía, ed. Mily Crevels and Pieter Muysken. La Paz: Plural Editores.

Guillaume, Antoine, And Françoise Rose. 2010. Sociative causative markers in South-American languages: A possible areal feature. Essais de Typologie et de Linguistique Générale: Mélanges offerts à Denis Creissels, ed. Frank Floricic, pp. 383-402. Lyon: Presses Universitaires de l'École Normale Supérieure.

Haude, Katharina. 2006. A grammar of Movima. Ph.D. dissertation, Radboud University Nijmegen.

2009. Hierarchical alignment in Movima. IJAL 75:513-32.

Heath, JefFrey. 1998. Pragmatic skewing in $1 \leftrightarrow 2$ pronominal combinations in Native American languages. IJAL 64:83-104.

Hemmauer, Roland. 2006. Aspectos del desarrollo histórico del sistema verbal de siriono (lengua tupí-guaraní de Bolivia). Guaraní y "Mawetí-Tupí-Guaranî’: Estudios históricos y descriptivos sobre una familia lingüística de América del Sur, ed. Wolf Dietrich and Haralambos Symeonidis, pp. 87-104. Berlin: LIT Verlag.

IgGesen, OLIVER. 2007. Case-marking in Chacobo: Alignment splits, a suprasegmental marker, and how tone sandhi messes it all up. Paper presented at the Workshop on Argument-Coding Systems in Bolivian Lowland Languages, CELIA, Villejuif, April 5-7, 2007.

Kaufman, Terrence. 1990. Language history in South America: What we know and how to know more. Amazonian Linguistics: Studies in Lowland South American Languages, ed. Doris Payne, pp. 13-67. Austin: University of Texas Press. 
PAYNe, Doris. 1990. Introduction. Amazonian Linguistics: Studies in Lowland South American Languages, ed. Doris L. Payne, pp. 1-10. Austin: University of Texas Press.

Rose, FrançoIsE. Forthcoming. Mojeño Trinitario. Lenguas de Bolivia, vol. 3, Oriente, ed. M. Crevels and P. Muysken. La Paz: Plural Editores.

SAITO, AKIRA. 2009. Fighting against a hydra: Jesuit language policy in Moxos. Beyond Borders: A Global Perspective of Jesuit Mission History, ed. Shinzo Kawamura and Cyril Veliath, pp. 350-63. Tokyo: Sophia University Press.

Sakel, Jeanette. 2004. A Grammar of Mosetén. Berlin and New York: Mouton de Gruyter.

VAlenzuela, Pilar M. 2000. Ergatividad escindida en waripano, yaminawa y shipibo konibo. Indigenous Languages of Lowland South America, ed. Hein van der Voort and Simon van de Kerke, pp. 111-28. Leiden: CNWS. n.d. Case-marking in Chacobo in Panoan perspective. Ms., Chapman University.

VAN DE KeRKe, Simon. 2006. Object cross-reference in Leko. What's in a Verb? Studies in Verbal Morphology of the Languages of the Americas, ed. Grazyna J. Rowicka and Eithne B. Carlin, pp. 171-88. Utrecht: LOT, Netherlands Graduate School of Linguistics, Utrecht University. VAN GiJn, Rik. 2006. A grammar of Yurakaré. Ph.D. dissertation, Radboud University Nijmegen. Villafañe, Lucrecia. 2004. Gramática Yuki: Lengua Tupí-Guaraní de Bolivia. Tucumán: Ediciones del Rectorado, Universidad Nacional de Tucumán.

Vuillermet, Marine. 2007. Double object constructions and the $-k a$ suffix: Two special features of Ese Ejja. Paper presented at the Workshop on Argument-Coding Systems in Bolivian Lowland Languages, CELIA, Villejuif, April 5-7, 2007.

. Forthcoming. A grammar of Bolivian Ese Ejja (Takana), an endangered Amazonian language. Ph.D. dissertation, Université Lumière Lyon 2.

ZÚÑIGA, FeRnANDO. 2006. Deixis and Alignment: Inverse Systems in Indigenous Languages of the Americas. Amsterdam and Philadelphia: John Benjamins. 